субъекта воли. Это могло бы дать более объективную картину ценностной системы у сербов, как в случае со свойствами пркос и инат, входящими в стереотип национального характера.

Черных П. Я. Историко-этимологический словарь современного русского языка : в 2 т. М., 1999.

DOI 10.31168/7996-2700-3.99

\author{
С. П. Праведников \\ Курск, Россия \\ spprav618@mail.ru
}

Курский государственный университет

\title{
Ономастическое пространство курской сказки
}

Приступая к анализу ономастического поля курского фольклора, сосредоточим свое внимание прежде всего на топонимической составляющей этого пространства, сузив само пространство за счет жанровой дифференциации. На первый план выходят русские народные сказки, записанные в Курском регионе в разное время. На сегодняшний день завершается большая работа по формированию корпуса курских эпических текстов. Большим подспорьем для всестороннего анализа фольклорных произведений являются лексикографические комплексы, методику разработки которых успешно осваивают курские ученые. Так, увидели свет «Балладные песни Курской губернии» и «Юмористические и сатирические песни Курской губернии». Каждый комплекс состоит из четырех частей: фольклорного мегатекста, алфавитно-частотного словника, частотного словаря и конкорданса [Бобунова, 2019]. Сейчас на очереди лексикографический комплекс народных сказок, записанных в 1863 г. в Тимском уезде Курской губернии [Белкин, 1863].

Топонимическая лексика, входящая в сказочный гипертекст определенной местности, зачастую является ярким свидетельством территориального своеобразия. Топонимы, фиксируемые фольклорными памятниками, обладают потенциальной способностью быть указателями региональной принадлежности того или иного текста. В силу разных

(C) Праведников С. П., 2019 
обстоятельств этот потенциал реализуется далеко не всегда. По свидетельству Ю. А. Новикова, такой жанр русского фольклора, как былина, характеризуется чрезвычайным обилием топонимов [Новиков, 2004], что нашло отражение и в северной сказке [Праведников, 2010, 200]. Курская сказка весьма осторожно использует топонимическую лексику. Приведем несколько характерных ситуаций, где это можно увидеть.

В курских сказках, вошедших в сборник А. Н. Афанасьева [19841985], находим топоним Крым-град, который не встречается ни в каких других текстах: «Пошел муж во Крым-град зелья купить, жене зельем живот лечить!» (№ 445). Отмечены и оттопонимические прилагательные, например новогородский: «Леший откликнулся, скинулся молодцом, новогородским купцом, прибежал и подарочек принес» (№ 97).

В сказках, записанных Ф. Белкиным [1863], функционирует существительное $P$ усь, причем возможно сочетание $P$ усь-кость, т. е. русская $\kappa о c m b$, к топонимии отношения не имеющее: «Прилятаить двенадцати

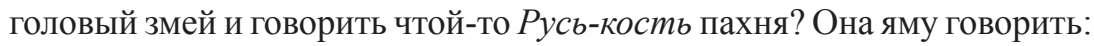
ты по Руси лятал и русскаго воздуху набралси» (№ 8). Географический объект может быть назван приблизительно, описательно, с использованием прилагательного, образованного от топонима: «Она приходит к мужу и расказала ему про это, и говорит: < .. > пойдем, Афанасьюшко, вы путь вы дорогу, вы иныя селы, в турецкия земли» (№ 11).

В активном использовании географических названий можно увидеть стремление придать как можно бо́льшую правдоподобность повествованию. По этой же причине рассказчики обычно называют точное место, где происходило действие, описываемое ими в сказкахбывальщинах или легендах; причем это место не обязательно должно быть связано с теперешним местожительством сказочника или с хорошо известными слушателям населенными пунктами или объектами микротопонимики, хотя чаще бывает именно так.

Во многих бытовых (и не только бытовых) сказках просматривается желание указать место действия.

Детализация пространства способствует не только погружению слушателей в сказочный мир, но и приданию большей значимости самому сказочнику, удовлетворению его стремления казаться человеком бывалым, много знающим. Чаще всего такая информация передается в искаженном виде и для искушенного слушателя выглядит неправдоподобной. 
Некоторая путаница в географических названиях не смущает сказителя, она, пожалуй, выступает как необходимое условие сказочного повествования; рассказчик легко оперирует топонимами, сводя в одну разные реки, называя страну городом и т. п.

Таким образом, топонимическая лексика наряду с диалектными и фольклорными словами наиболее тесно связана с фактором пространственной распределенности и вследствие этого является прямым доказательством территориальной маркированности сказочного мегатекста.

Афанасьев - Народные русские сказки А. Н. Афанасьева : в 3 т. М., 1984-1985.

Белкин Ф. Сказки, записанные в Тимском уезде // Тр. Курск. губ. стат. ком. Курск, 1863. Вып. 1. С. 518-542.

Бобунова М. А. Лексикографический комплекс фольклорных текстов. Песни Курской губернии. Курск, 2019.

Новиков Ю. А. Местный колорит в былинах олонецких сказителей // Кижский вестн. 2004. Вып. 9. URL: http://kizhi.karelia.ru/library/vestnik-9/322.html.

Праведников С. П. Основы фольклорной диалектологии. Курск, 2010.

DOI 10.31168/7996-2700-3.100

\section{И. С. Просвирнина, Мэнцянь Цзя}

Уральский федеральный университет

Екатеринбург, Россия

prosvirniny@mail.ru

\section{Оппозиция «трудный — простой» в русских и китайских толковых словарях}

Предмет исследования - развитие значений лексем трудный и простой (в рамках изучения оппозиций со значением меры), формирование современных антонимических пар (комплексов) и сопоставление этих элементов языковой картины мира в русской и китайской лингвокультурах.

В «Толковом словаре живого великорусского языка» В. И. Даля труд (среди прочих толкований) - 'все, что требует усилий, старанья и заботы; всякое напряженье телесных или умственных сил; все,

(С Просвирнина И. С., Цзя М., 2019 